\title{
Mitigasi Dan Arahan Pengelolaan Air Asam Tambang Melalui Hutan Rawa Buatan Di Lahan Pasca Tambang
}

\section{Acid Mine Drainage Treatment Strategy and Mitigation through Constructed Swamp Forest in Post Mining Area}

\author{
Armaiki Yusmur ${ }^{\mathrm{a}}$, Muhammad Ardiansyah ${ }^{\mathrm{b}}$, Irdika Mansur ${ }^{\mathrm{c}}$ \\ ${ }^{a}$ Program Studi Mitigasi Bencana Kerusakan Lahan, Departemen Ilmu Tanah dan Sumberdaya Lahan, Fakultas Pertanian, Institut \\ Pertanian Bogor, Kampus IPB Darmaga, Bogor 16680, Indonesia [+62 251 8323848] \\ ${ }^{\mathrm{b}}$ Program Studi Mitigasi Bencana Kerusakan Lahan, Departemen Ilmu Tanah dan Sumberdaya Lahan, Fakultas Pertanian, Institut \\ Pertanian Bogor, Kampus IPB Darmaga, Bogor 16680, Indonesia [+62 251629 360] \\ ${ }^{\mathrm{c}}$ Departemen Silvikultur, Fakultas Kehutanan, Institut Pertanian Bogor, Kampus IPB Darmaga, Bogor 16680, Indonesia [+62 251 \\ 8323848]
}

\section{Article Info:}

Received: 15 - 01 - 2018

Accepted: 22 - 04 - 2019

\section{Keywords:}

AMD, UAV, $\mathrm{pH}$, phytoremediation, wetland, swamp forest

\section{Corresponding Author:} Armaiki Yusmur Regional Research Centre for Tropical Biology (SEAMEO BIOTROP);

Tel. +62-251-8323848

Email: micky@biotrop.org

\begin{abstract}
The application of remote sensing using Unmanned Aerial Vehicle (UAV) technology to identify distribution of Acid Mine Drainage (AMD) as part of mitigation process has been done in PT. Jorong Barutama Greston. UAV imagery was interpreted visually to produce land cover map. Bare land area from land cover map is used as the boundary of the analysis area for the mitigation of AMD source. Color of soil in UAV images is used as training area for supervised classification to differentiate different $p H$. The result shows distribution of soil with pH between 2-3 is $1.2 \mathrm{ha}, \mathrm{pH} 3-4$ is $4.5 \mathrm{ha}$, and pH 4-5 is 9 ha. This analysis can show that mapping results using aerial photo is effective to identify $\mathrm{pH}$ of soil in bare land as a source of acid to water in void and it used as input for revegetation and swamp forest planning as biophytoremediation efforts. Swamp forest as a wetland is one recomendation for sustainable water management on mine to increase $\mathrm{pH}$ and reduce heavy metal content. The success of constructed swamp forest as passive treatment for bio-phytoremediation is determined by the selection of plant species, site location, design and construction of swamp forest and maintenance. Typha latifolia, Salvinia sp., Fimbristylis globulosa, Chrysopogon zizanioides, Melaleuca leucadendra, Melaleuca cajuputi, Nauclea subdita and Nauclea orientalis L. are recom-mended as local selected plants for phytoremediation. Obtained six variables that significantly affected to determination of site location for constructed swamp forest are elevation $(T)$, slope $(S)$, land cover $(L)$, cathment area $(C)$, distance from channel $(K)$ and distance from the monitoring pool $(P)$. The model $X=0.2 T+0.2 S+0.1 L+0.15 C+0.3 K+$ $0.05 P$ applied to find very suit-able area with $\alpha=0.05$ and the $R$-square $(R 2)$ value $93.4 \%$.
\end{abstract}

How to cite (CSE Style $8^{\text {th }}$ Edition):

Yusmur A, Ardiansyah M, Mansur I. 2019. Mitigasi dan arahan pengelolaan air asam tambang melalui hutan rawa buatan di lahan pasca tambang. JPSL 9(3): 566-576. http://dx.doi.org/10.29244/jps1.9.3.566-576.

\section{PENDAHULUAN}

Kegiatan penambangan terbuka (open pit mining) merupakan kegiatan yang mengubah bentuk rona awal lahan dan berpotensi menyebabkan berbagai permasalahan lingkungan seperti gangguan tanah, air dan polusi 
udara. Setelah kegiatan penambangan berakhir, perusahaan harus mereklamasi lahan yang telah ditambang. Sebagian area reklamasi terkadang masih terdapat void (lubang tambang yang terisi air) akibat perencanaan pasca tambang yang kurang baik. Hal ini berpotensi terdampak air asam tambang. Oleh sebab itu perusahaan harus memantau kondisi air dalam void dan mengalirkan airnya ke perairan bebas sesuai batas baku mutu lingkungan.

Air asam tambang (AAT) adalah salah satu dampak lingkungan yang terjadi akibat reaksi senyawa sulfat dan ion besi pada batuan yang berpotensi mengandung asam (Potential Acid Forming/PAF). Ketika ion besi teroksidasi dan menghasilkan oksida besi terhidrasi, keasaman pada lingkungan sekitarnya meningkat (Segupta 1993). AAT akan selalu terjadi selama batuan sisa pertambangan (overburden) tersingkap dan teroksidasi oleh air dan mengalir ke saluran drainase, sungai, rawa, danau dan air tanah. Hal ini akan berdampak matinya organisme perairan dan meracuni tanah akibat $\mathrm{pH}$ air yang rendah dan konsentrasi logam berat yang tinggi serta elemen beracun lainnya.

Perusahaan tambang meningkatkan kualitas air akibat AAT dengan memberikan kapur tohor. Hal ini membutuhkan biaya yang mahal dan merupakan teknik yang tidak berkelanjutan jika nanti ijin konsesi perusahaan habis. Sehingga perlu dilakukan mitigasi sumber penyebab air asam tambang yang terus terjadi pada void dan menemukan cara pengolahan air asam tambang yang berkelanjutan dan berbiaya murah. Salah satu teknologi yang dimanfaatkan adalah teknologi penginderaan jauh dan Sistem Informasi Geografi (SIG) yang diaplikasikan untuk perencanaan hutan rawa sebagai teknologi penanganan AAT secara pasif. Penanganan AAT dengan kapur atau metoda lahan basah adalah praktek-praktek dalam kegiatan reklamasi yang sudah biasa dilaksanakan (Iskandar et al. 2011), namun metode pengelolaan air secara pasif yang efektif dan membutuhkan pengelolaan yang minimal belum banyak ditemukan. Pembuatan hutan rawa buatan merupakan salah satu ide untuk pengelolaan AAT secara pasif agar air yang keluar dari kolam pengendapan memenuhi baku mutu lingkungan. Pemilihan tanaman yang tepat dapat meningkatkan keberhasilan revegetasi sehingga dapat membantu mengurangi aliran permukaan yang bersifat asam. Tujuan penelitian adalah menyusun arahan pengelolaan dan mitigasi air asam tambang melalui hutan rawa buatan di lahan pasca tambang.

\section{METODE}

\section{Lokasi dan Waktu Penelitian}

Penelitian ini dilaksanakan pada bulan Februari sampai Desember tahun 2017 di PT. Jorong Barutama Greston, yang terletak di Desa Swarangan, Kecamatan Jorong, Kabupaten Tanah Laut, Provinsi Kalimantan Selatan (Gambar 1). Tanah pada areal kegiatan tambang batubara di PT. JBG didominasi oleh tanah ultisol. Topografi wilayah tambang PT. JBG datar, bergelombang, dan berbukit. Lokasi PT. JBG dipengaruhi oleh iklim tropika basah dengan curah hujan rata-rata bulanan berkisar antara 95 - $301 \mathrm{~mm}$ dan merata sepanjang tahun.

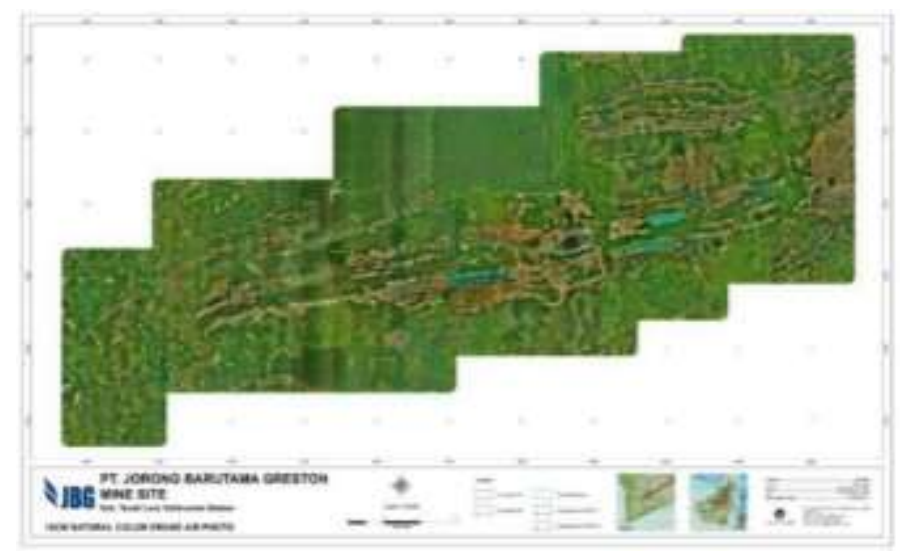

Gambar 1 Peta Lokasi IUP PT. Jorong Barutama Greston 


\section{Metode Pengumpulan dan Analisis Data}

Analisis data dilakukan menggunakan foto udara yang direkam melalui pesawat tanpa awak (Unmanned Aerial Vehicle/UAV). Perangkat lunak pengolahan citra ER Mapper dan ArcGIS digunakan sebagai tools untuk membantu analisis.

\section{Membuat peta wilayah pengelolaan dan penutupan lahan terkini}

Data elevasi dijital (DEM) yang dihasilkan dari data kontur pada area kelompok pengelolaan diolah untuk membuat batas area tangkapan air dan arah aliran, yang selanjutnya digunakan sebagai batas wilayah pengelolaan AAT. Peta wilayah pengelolaan menjadi peta dasar untuk memotong foto udara. Hasil pemotongan foto udara diinterpretasi secara visual untuk menghasilkan peta tutupan lahan terkini. Selanjutnya tutupan lahan ini dijadikan sebagai input penentuan area penyumbang asam dan lokasi yang sesuai untuk hutan rawa.

\section{Identifikasi sebaran lahan asam sebagai sumber air asam tambang pada void menggunakan foto udara}

Sebaran tanah dengan $\mathrm{pH}$ rendah sebagai lahan penyumbang AAT diidentifikasi dengan klasifikasi terbimbing berdasarkan perbedaan warna tanah pada foto udara. Pengambilan sample $\mathrm{pH}$ tanah dilakukan sebagai area contoh untuk proses klasifikasi. Pengujian $\mathrm{pH}$ tanah dilakukan di Laboratorium Tanah SEAMEO BIOTROP. Peta sebaran $\mathrm{pH}$ tanah di wilayah studi digunakan sebagai rekomendasi pengolahan tanah di sekitar void dan pemilihan jenis vegetasi yang sesuai serta menjadi input untuk perencanaan hutan rawa.

\section{Membuat arahan pengelolaan dan perencanaan lokasi hutan rawa dan pemilihan jenis vegetasi yang adaptif terhadap AAT}

Analisis spasial digunakan untuk penentuan kawasan yang sangat sesuai untuk menjadi hutan rawa. Data peta penutupan lahan, kemiringan lahan, elevasi, catchment area, jarak dari saluran drainase dan jarak dari kolam monitoring digunakan sebagai input penentuan area hutan rawa. Area hutan rawa yang dihasilkan dan lahan yang masih terbuka dijadikan untuk perencanaan revegetasi.

\section{HASIL DAN PEMBAHASAN}

\section{Penentuan Wilayah Pengelolaan AAT}

Peta topografi atau data DEM merupakan data yang dapat dimanfaatkan untuk membatasi daerah tangkapan air dan arah aliran. Daerah tangkapan air (catchment area) inilah yang menjadi wilayah pengelolaan AAT. Batasan area ini dapat menjelaskan luasan dan karakteristik wilayah studi yang terdampak air asam tambang.

Area penelitian terletak di salah satu bagian dari sub-catchment Wilayah Pengelolaan I di PT. JBG (Gambar 2) dengan luas area 435. ha dari luas total catchment 423.8 ha. Area penelitian ini merupakan area penimbunan dari penambangan Pit UEC yang sebagian sudah ditanami dan sebagian masih berupa lahan terbuka serta memiliki void dengan luas 9,1 ha. Daerah tangkapan air pada area penelitian ini memberikan kontribusi yang besar terhadap pembentukan air asam tambang yang aliran limpasannya masuk langsung ke dalam badan air void UEC. 


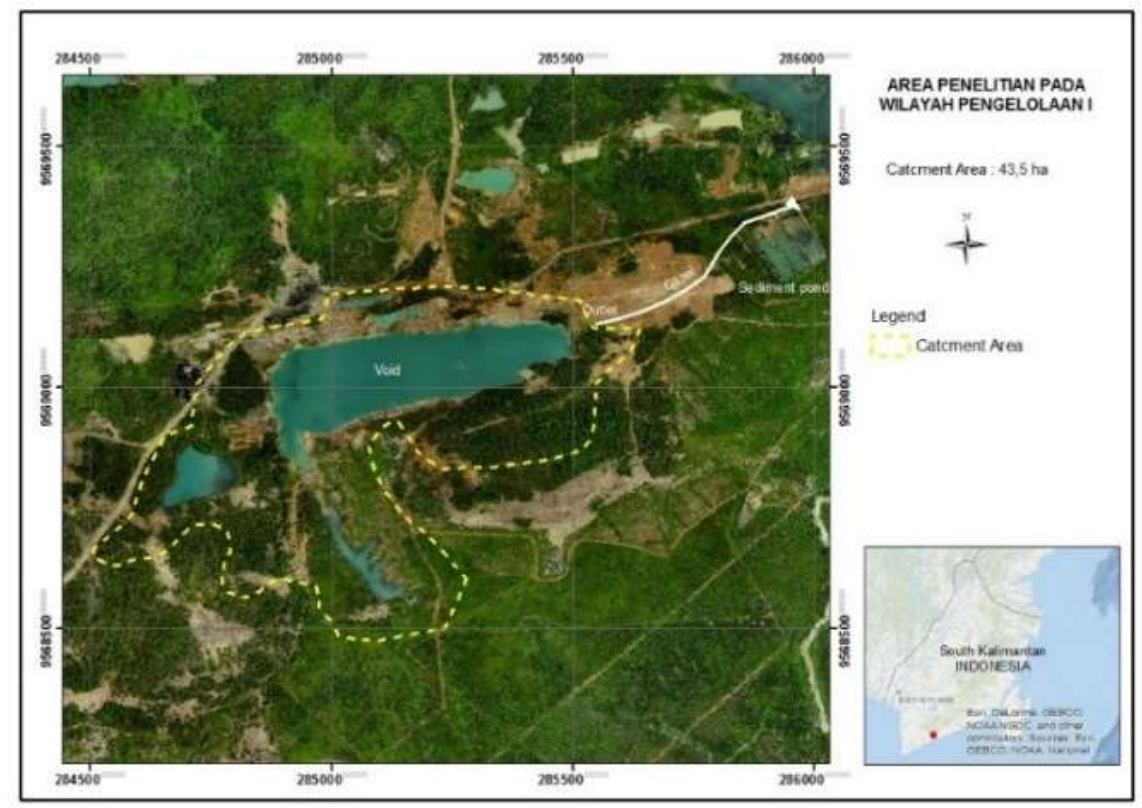

Gambar 2 Area penelitian

\section{Pemanfaatan Penginderaan Jauh untuk Mengetahui Penutupan Lahan}

Teknologi penginderaan jauh modern saat ini memberikan kesempatan yang sangat baik untuk memantau kerusakan lingkungan pasca tambang. Ketersediaan data, penutupan awan dan harga adalah beberapa kendala yang banyak ditemui dalam pemanfaatan data citra resolusi tinggi. Wilayah yang terpencil dan merupakan kawasan hutan menyebabkan pilihan ketersediaan data sangat kurang. Karakterikstik keawanan yang kecilkecil dan menyebar merata di Pulau Kalimantan dimana penelitian dilakukan menyebabkan kurang baiknya kualitas data. Oleh sebab itu perekaman poto udara dengan pesawat UAV digunakan dalam penelitian ini.

Foto udara diinterpretasi secara visual untuk mendapatkan jenis penutupan lahan. Peta penutupan lahan yang menggambarkan sebaran lahan terbuka, vegetasi dan tubuh air yang terdapat di area penelitian dapat diidentifikasi seperti Gambar 3. 33.8\% area merupakan lahan terbuka, $43 \%$ vegetasi dan $23.2 \%$ merupakan tubuh air.

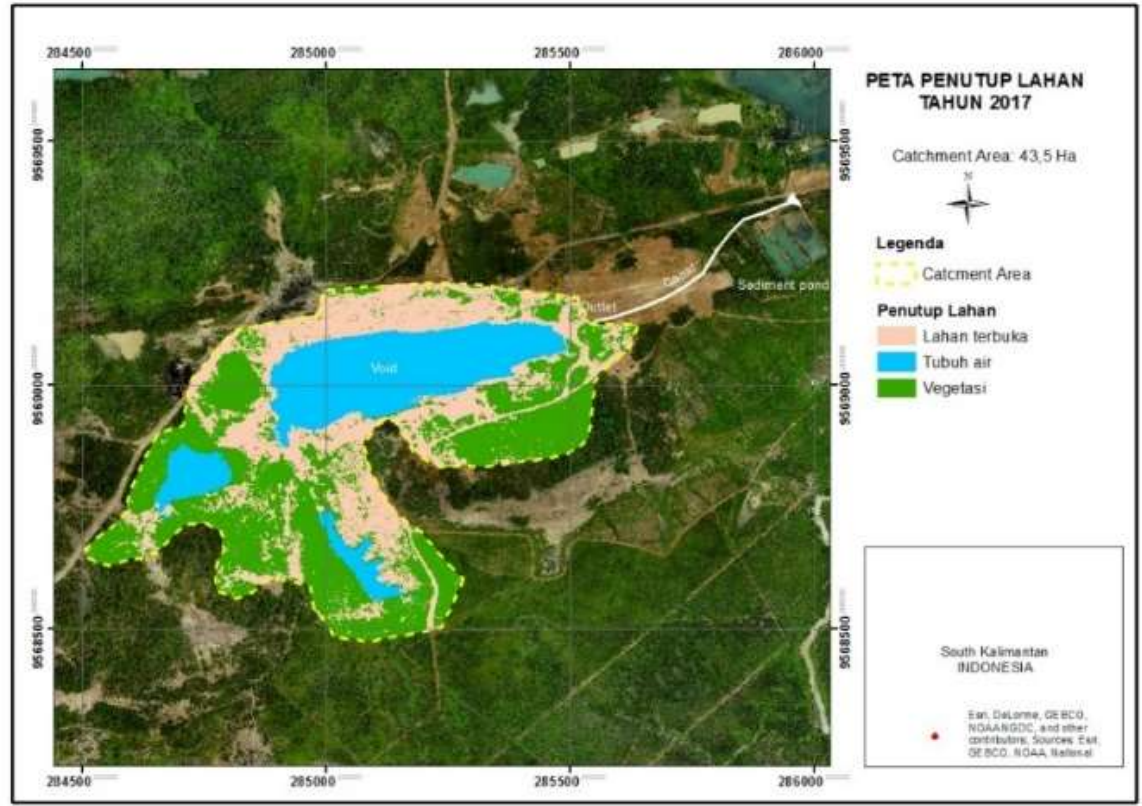

Gambar 3 Peta Penutupan Lahan Area Penelitian Tahun 2017 


\section{Pemanfaatan Penginderaan Jauh untuk Identifikasi Sumber Lahan Penyumbang AAT}

Foto udara yang dihasilkan dari UAV memberikan karakteristik warna yang berbeda pada setiap obyek yang direkam pada area catchment. Lahan terbuka memiliki warna putih sampai kehitaman menunjukan kondisi $\mathrm{pH}$ tanah yang berbeda. Pendekatan ini divalidasi dengan pengambilan sampel tanah untuk pengecekan $\mathrm{pH}$ tanah di laboratorium.

Metode klasifikasi terbimbing digunakan untuk menghasilkan distribusi peta sebaran keasaman $(\mathrm{pH})$ tanah di area penelitian. Area lahan terbuka yang diperoleh dari peta penutupan lahan dijadikan pembatas (masking) melalui proses pemotongan untuk memperoleh foto udara lahan terbuka saja. Selanjutnya data ini diinterpretasi menggunakan metode klasifikasi terbimbing dengan bantuan titik sampel yang diperoleh saat survey. Analisis citra menunjukkan terdapat 3 kelas wilayah dengan $\mathrm{pH}$ yang berbeda (Gambar 4).

Hasil analisis menunjukkan bahwa terdapat 1.2 ha lahan terbuka memiliki pH tanah antara 2 sampai 3 , 4.5 ha antara 3 sampai 4 dan 9 Ha memiliki pH antara 4 sampai 5. Hasil analisis ini diuji akurasi menggunakan overall accuracy dan index kappa (Tabel 1). Berdasarkan perhitungan dihasilkan overall accuracy $73 \%$ dengan index Kappa 52\%.

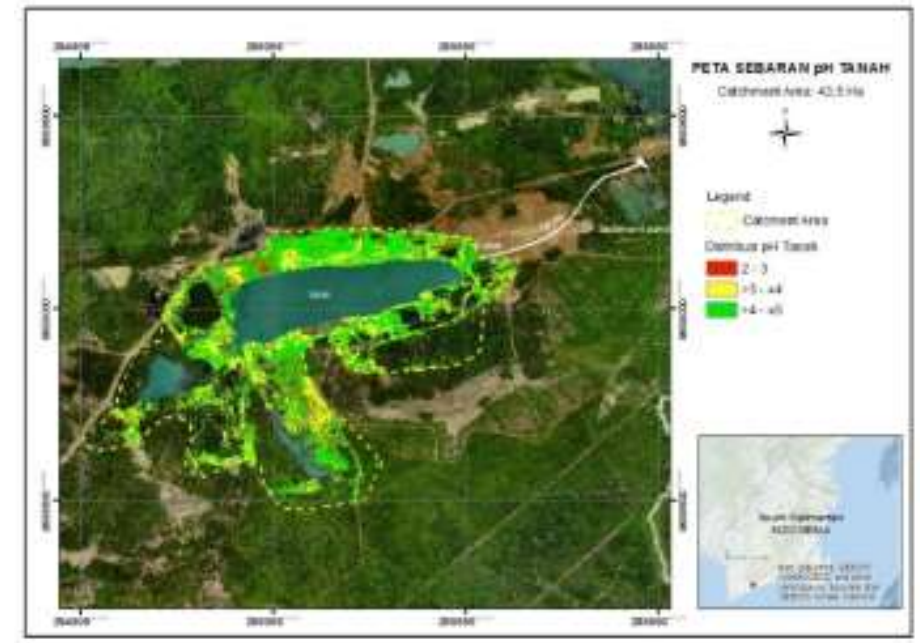

Gambar 4 Peta sebaran keasaman $(\mathrm{pH})$ tanah di area penelitian

Tabel 1 Overall accuracy dan index Kappa hasil analisis

\begin{tabular}{|c|c|c|c|c|c|}
\hline & \multirow{2}{*}{$\mathrm{pH}$} & \multicolumn{4}{|c|}{ Referensi } \\
\hline & & $2-3$ & $3-4$ & $4-5$ & Total \\
\hline \multirow{4}{*}{ 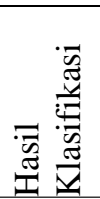 } & $2-3$ & 1 & 0 & 1 & 2 \\
\hline & $3-4$ & 2 & 2 & 0 & 4 \\
\hline & $4-5$ & 0 & 1 & 8 & 9 \\
\hline & Total & 3 & 3 & 9 & 15 \\
\hline
\end{tabular}

Setelah mengetahui lahan penyumbang asam pada air di void, sebaran $\mathrm{pH}$ tanah disekitarnya, dan mengetahui karakteristik area penelitian, data ini selanjutnya digunakan untuk mengembangkan rekomendasi arahan pengelolaan air asam tambang, pemilihan vegetasi untuk revegetasi, dan prioritas perbaikan kondisi air yang keluar menuju sungai dari lokasi penelitian dengan menggunakan hutan rawa.

\section{Arahan Pengelolaan dan Perencanaan Lokasi Hutan Rawa Sebagai Usaha Bio-fitoremediasi AAT Berkelanjutan}

Kondisi tanah dengan kandungan $\mathrm{pH}$ yang terlalu masam, kandungan logam berat seperti $\mathrm{Fe}, \mathrm{Al}$, dan $\mathrm{Mn}$ yang tinggi di lahan pasca tambang mengakibatkan pertumbuhan tanaman menjadi terganggu (Widiyatmoko et al. 2017). Pemberian kapur dan pupuk kimia merupakan solusi yang cepat dan nyata dalam mengembalikan 
kesuburan pada lahan asam (Alibasyah 2016), namun metode ini membutuhkan biaya yang mahal. Penggunaan bahan organik dan kompos sangat direkomendasikan untuk perbaikan kualitas lahan dan peningkatan keberhasilan revegetasi dengan biaya lebih murah. Bahan organik dapat menurunkan unsur Al terlarut dan meningkatkan $\mathrm{pH}$ dan menjadi sumber hara esensial bagi pertumbuhan tanaman. Penambahan bahan organik juga dapat memperbaiki struktur tanah, meningkatkan kapasitas tukar kation tanah dan menjadi bahan makanan bagi mikroba dan mikro fauna tanah dalam menambah kesuburan tanah (Muzaiyanah dan Subandi 2016). Pemberian bahan organik disarankan sebanyak $3-5 \mathrm{~kg}$ per lubang tanam. Juniarto (2017) menjelaskan bahwa penggunaan kompos $5 \mathrm{~kg}$ memberikan pengaruh yang terbaik dalam peningkatan diameter, tinggi dan jumlah daun tanaman Jabon di lahan pasca tambang. Efisiensi pengadaan bahan organik dapat dilakukan dengan mencari sumber pupuk organik yang mudah didapatkan di sekitar area pasca tambang atau dari tanaman legume dan cover crop yang digunakan untuk mengurangi erosi, kekeringan, tumbuhnya gulma alangalang dan mengurangi aliran asam ke void. Usaha ini dilakukan sebagai inisiasi bentuk siklus hara tertutup di hutan.

Penanaman cover crop dan tanaman cepat tumbuh serta pemilihan spesies tanaman lokal yang berperakaran dalam yang toleran terhadap $\mathrm{Al}$ yang tinggi dan $\mathrm{pH}$ yang rendah perlu dipertimbangkan untuk menunjang keberhasilan revegetasi area reklamasi di lahan pasca tambang (Peraturan Pemerintah No. 78/2010, Peraturan Mentri ESDM No. 7/2014). Pemilihan jenis lokal disesuaikan dengan fungsi kawasan dan rencana pasca tambang. Area penelitian yang merupakan kawasan hutan harus dihutankan kembali dengan menanam jenis yang tahan terhadap tanah asam. Beberapa jenis yang direkomendasikan yaitu Sungkai (Perunema inerme), Sengon putih (Paraserienthes falcataria), Mahoni (Swietenia mahagoni), Jabon (Anthocephalus cadamba), Meranti (Dipterocorpus Spesi), Galam (Melaleuca leucadendra), Kayu Putih (Melaleuca cajuputi), pinus (Pinus mercusii), Gempol (Nuclea orientalis) dan Beringin (Ficus benjamina). Untuk tanaman penutup tanah dan penghasil bahan organik direkomendasikan sereh wangi, Mucuna chochinensis, Calliandra, Gliricidia dan Peltophorum.

Untuk pengelolaan air asam tambang direkomendasikan menggunakan hutan rawa buatan. Pemanfaatan lahan basah berupa hutan rawa sebagai metode passive treatment dalam upaya mengurangi dan menghilangkan berbagai cemaran akibat aktivitas industri, pertambangan dan domestik sudah lama dikembangkan dan menjadi pilihan utama (Norton 1992; Mays dan Edwards 2001; Sasaki et al. 2003; Sheoran dan Sheoran 2006; Dhir 2013; Tuheteru 2015; Denholm 2016). Lahan basah terbukti dapat meningkatkan pH dan menurunkan kadar logam terlarut (Dhir 2013; Tuheteru 2015; Denholm 2016). Penggunaan tandan kosong sebanyak 300 ton dan 120 ton kompos sebagai subtrat dasar kolam dan tanaman hyperaccumulator di hutan rawa buatan di area penelitian dengan luas $3300 \mathrm{~m} 2$ dan kapasitas $1500 \mathrm{~m} 3$ dapat meningkatkan $\mathrm{pH}$ air dari 3 menjadi 6 dalam waktu 2 jam dalam kondisi air tidak mengalir. Hal ini didukung oleh penelitian Rafsanjani (2015) bahwa semakin tinggi dosis bahan organik semakin meningkat nilai $\mathrm{pH}$ di setiap waktu penggenangan. Beberapa faktor penentu keberhasilan lahan basah dalam fitoremediasi AAT adalah lokasi, pemilihan jenis tanaman, desain dan konstruksi lahan basah serta pemeliharaan (Kivaisi 2001; Dhir 2013; Denholm 2016).

\section{Penentuan lokasi yang sesuai untuk hutan rawa buatan}

Penerapan teknik lahan basah untuk penerapan fitoremediasi AAT tentunya membutuhkan perencanaan yang matang. Pemilihan lokasi yang sesuai sangat penting dan menentukan langkah awal dalam pembangunan lahan basah. Dalam penelitian ini dilakukan kajian analisis kesesuaian lahan untuk hutan rawa sebagai penerapan fitoremediasi AAT pada kawasan penelitian agar metode ini dapat diterapkan pada kawasan yang lain.

Kebutuhan data untuk analisa lokasi hutan rawa adalah penutupan lahan, asessibilitas (letak kolam penataan/monitoring, letak saluran/kanal), dan kondisi fisik wilayah meliputi kemiringan lahan, elevasi dan area catchment. Pemilihan lokasi dilakukan dengan menggabungkan kriteria tersebut dengan metode overlay data spasial. Sistem Informasi Geografis (SIG) digunakan untuk menganalisa lokasi yang sesuai untuk melakukan analisis multi kriteria. Penilaian oleh para pakar (Expert judgement) digunakan sebagai metode 
untuk menentukan bobot dari setiap variable yang telah dipilih. Berdasarkan pendapat para ahli diperoleh persamaan penentuan lokasi untuk lokasi lahan basah buatan sebagai berikut:

$$
\mathrm{X}=0.2 \mathrm{~T}+0.2 \mathrm{~S}+0.1 \mathrm{~L}+0.15 \mathrm{C}+0.3 \mathrm{~K}+0.05 \mathrm{P}
$$

dimana :
$\mathrm{X}=$ Kesesuaian lokasi untuk lahan basah/hutan rawa buatan
$\mathrm{T}=$ Elevasi (mdpl)
$\mathrm{L}=$ Penutupan lahan
$\mathrm{S}=$ Kemiringan lahan $(\%)$
$\mathrm{C}=$ Lokasi catchment
$\mathrm{K}=$ Jarak dari saluran/kanal
$\mathrm{P}=$ Jarak dari kolam pemantauan

Berdasarkan nilai akhir X pada persamaan 1, kesesuaian lokasi dibagi atas empat lokasi yaitu :

- Lokasi yang sangat sesuai (SS) memiliki nilai 5

- Lokasi yang sesuai (S) memiliki nilai 4

- Lokasi yang tidak sesuai (TS) memiliki nilai 3

- Lokasi yang sangat tidak sesuai (STS) memiliki nilai 2

- Lokasi yang dilarang (restricted) memiliki nilai 0

Hasil analisa diatas dihasilkan lokasi yang sesuai untuk lahan basah buatan adalah seperti Gambar 5 .

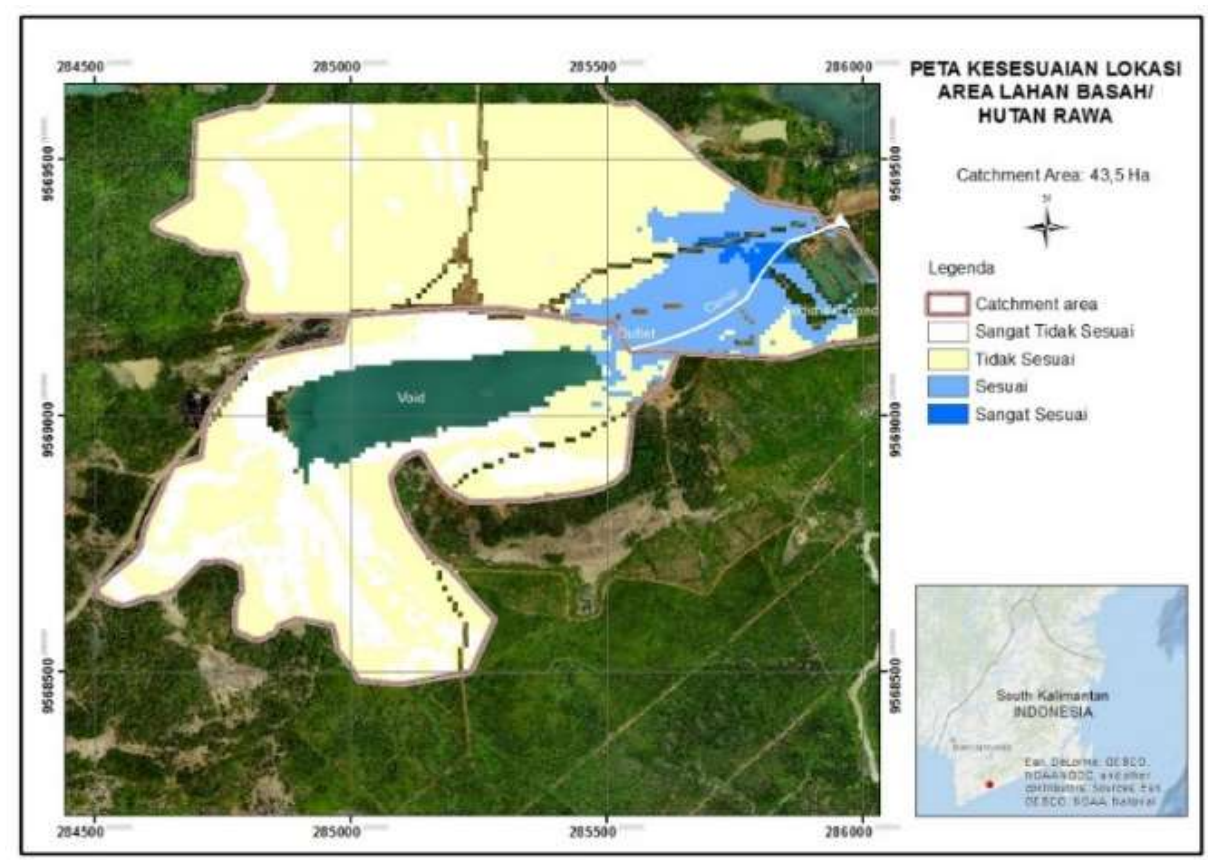

Gambar 5 Peta kesesuaian lokasi hutan rawa buatan

\section{Pemilihan Jenis Tanaman}

Pemilihan jenis tanaman toleran terhadap $\mathrm{pH}$ rendah, tahan terhadap genangan dan toksik logam berat perlu dilakukan. Pemanfaatan tanaman yang dapat tumbuh dan berkembang pada air asam yang tergenang (lahan basah) menjadi salah satu faktor penentu keberhasilan fitoremediasi. Menurut Kivaisi (2001), salah satu kelemahan lahan basah AAT adalah pengetahuan pengelola tentang ekologi lahan basah di tropika dan jenis asli masih terbatas. Selama ini, tumbuhan yang digunakan di lahan basah umumnya didominasi oleh bangsa rerumputan (monokotil) dan jenis herba lainnya seperti Eriphorum angustiolium, Eleocharis sp., Juncus 572 
inflexus, Phragmites australis, Salvinia sp. dan Typha latifolia dan lainnya. Jenis rumput dan tanaman air lokal yang tahan asam yang direkomendasikan di area penelitian dan banyak ditemui yaitu Typha latifolia, Salvinia sp., Fimbristylis globulosa, Chrysopogon zizanioides. Sedangkan jenis tanaman kehutanan lokal penghasil kayu yang direkomendasikan adalah Melaleuca leucadendra, Melaleuca cajuputi, Nauclea subdita dan Nauclea orientalis L.

\section{Desain dan konstruksi hutan rawa buatan}

Desain dan konstruksi hutan rawa buatan dalam penelitian ini mengacu pada standar yang dipakai oleh Wetland Stewarship Partnership tentang restorasi dan pengembangan lahan basah. Pembuatan hutan rawa buatan diharapkan menyerupai lahan basah alami yang ditanami pohon dengan bagian tepi kolam dibuat agak landai. Kelerengan yang kurang dari 5\%, memilih daerah aliran sungai kecil yang mengalir ke lahan basah, menghindari penggunaan struktur pipa, dan menanam tanaman spesies lokal dapat meminimalisasi perawatan (WSP 2009). Beberapa metode digabungkan dalam mendesain lahan basah seperti penggunaan batu gamping, aliran vertikal pada kolam yang dilapisi bahan organik dan batu gamping (vertical flow pond) dan penggunaan tanaman lokal sebagai pereduksi logam berat (Danehy 2002; Nairm 2016; Denholm 2016). Kunci dari keberhasilan metode lahan basah adalah pola aliran yang menyebar, kedalaman permukaan air yang dangkal dan pertumbuhan tanaman lokal yang kuat menjadi atribut kunci yang mendorong fungsi peningkatan kualitas air yang diinginkan. Berdasarkan faktor kunci tersebut maka dirancanglah lahan basah untuk pengolahan air asam tambang pada area penelitian dengan desain seperti Gambar 6. Lahan basah terdiri dari kolam pengendap lumpur, kolam kompartemen I, II, III dan hamparan batu gamping.

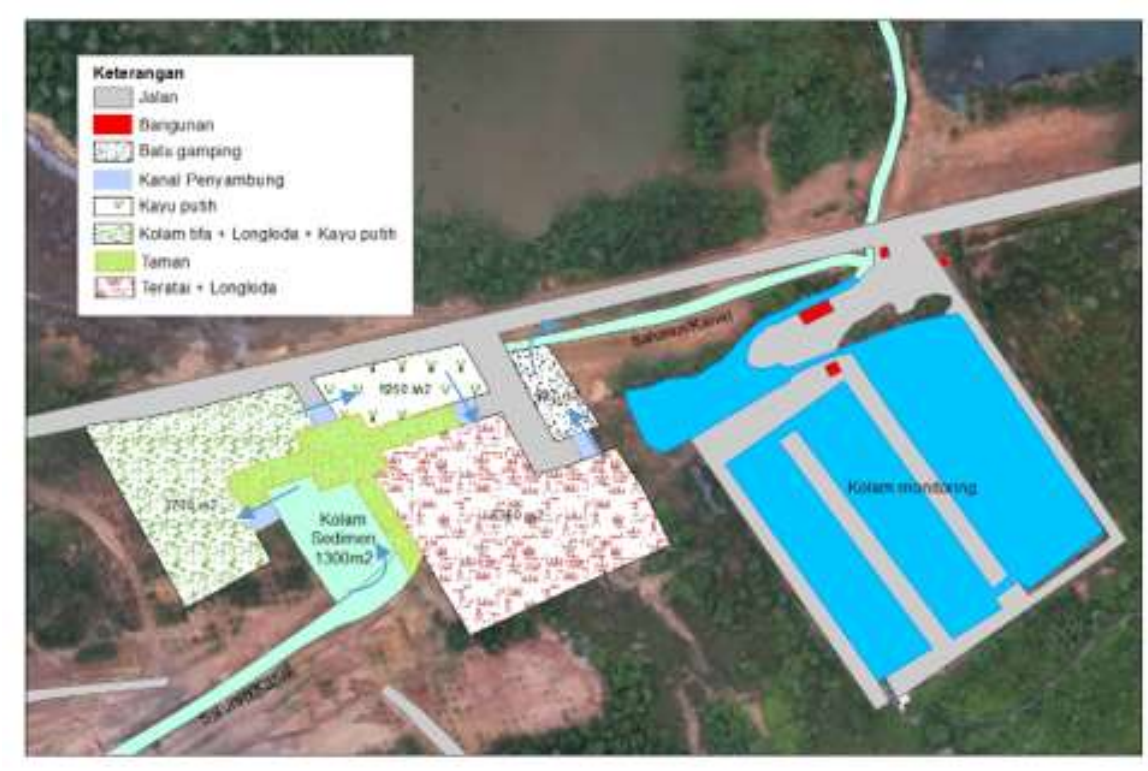

Gambar 6 Desain hutan rawa pada area penelitian

\section{Kolam sedimen (pengendap lumpur)}

Aliran air yang keluar dari void akan mengalir di sepanjang saluran kanal. Dinding kanal yang terbuat dari tanah berpotensi membawa partikel sedimen tanah sehingga harus ditampung di kolam pengendap lumpur. Kolam pengendap lumpur ini berfungsi sebagai tempat mengendapkan lumpur, atau material padatan yang bercampur dari limpasan yang disebabkan adanya aktifitas penambangan maupun karena erosi. Disamping tempat pengendapan sedimen, kolam ini menjadi bak kontrol bagi perusahaan untuk pemeliharaan lahan basah. 
Pada bagian ini juga berfungsi untuk penyerapan dan proses oksidasi Fe. Kolam ini dirancang seperti kolam biasa dengan dinding dan dasar masih dari tanah.

\section{Kolam kompartemen I}

Air dari kolam pengendap lumpur akan dialirkan melalui kanal terbuka ke kolam kompartemen I. Kolam kompartemen I dirancang berfungsi untuk mengaktifkan bakteri pereduksi sulfat dengan mendesain dasar kolam dilapisi $30 \mathrm{~cm}$ bahan organik yang terbuat dari tandan kosong dan ditutupi oleh tanah top soil dan kompos. Bahan organik yang ada berfungsi untuk menaikan $\mathrm{pH}$ air, menjadi tempat hidup bakteri pereduksi sulfat dan juga berfungsi sebagai media tumbuh bagi Typha sp yang ditanam diatas lapisan tanah ini. Jenis tumbuhan ini memiliki potensi sebagai penyerap jenis logam berat seperti Al dan As (Bonanno dan Cirelli, 2017). Ketinggian air pada kolam ini dan kolam seterusnya diusahakan setinggi $20-30 \mathrm{~cm}$.

\section{Kolam kompartemen II}

Setelah melewati kolam kompartemen I, air dialirkan ke kolam kompartemen II yang ditanami Typha sp, kayu putih dan longkida (Nauclea orientalis L.). Bagian dasar kolam kompartemen II disusun seperti kolam kompartemen satu yang terdiri dari tandan kosong, tanah top soil dan kompos. Penanaman kayu putih dan longkida bermanfaat untuk dapat menyerap dan mengakumulasi $\mathrm{Fe}, \mathrm{Mn}, \mathrm{Cu}, \mathrm{Zn}$ dan $\mathrm{Pb}$ (Tuheteru 2015).

\section{Kolam kompartemen III}

Desain lahan basah di kolam ketiga mengalokasikan jenis tumbuhan air eceng gondok (Eichhornia crassipes), akar wangi (Chrysopogon zizanioides) dan longkida (Nauclea orientalis L.). Jenis tanaman lain yang dapat ditanam juga adalah bangkal. Eceng gondok ini dapat dijadikan indikator terhadap kualitas air yang baik sebelum dialirkan ke perairan bebas. Logam $\mathrm{Pb}, \mathrm{Cd}, \mathrm{Cu}, \mathrm{Zn}, \mathrm{Mn}, \mathrm{Cr}, \mathrm{Hg}$, dan Ni merupakan jenis logam yang dapat diserap oleh eceng gondok (Schneider et al. 1995; Chunkao et al. 2012). Selain itu penanaman akar wangi (Chrysopogon zizanioides) juga bisa menjadi alternatif untuk penyerapan logam $\mathrm{Fe}, \mathrm{Mn}, \mathrm{Mg}, \mathrm{Cu}, \mathrm{Zn}$, $\mathrm{Ni}, \mathrm{Cr}, \mathrm{Cd}$ dan $\mathrm{Pb}$ (Gautam dan Agrawal, 2017). Jenis tanaman-tanaman tersebut diatas merupakan jenis yang berperan dan berpotensi sebagai penyerap logam berat yang masih tersisa. Air keluaran dari kolam kompartemen III dialirkan ke kolam monitoring melewati sebuah bagian kanal yang dipapar dengan hamparan batu gamping untuk mengikat sisa sisa pirit yang ada.

\section{SIMPULAN}

Penelitian ini menjelaskan penerapan teknik penginderaan jarak jauh yang dapat digunakan oleh praktisi pertambangan untuk pengelolaan lahan yang terkena dampak AAT dalam pengambilan keputusan terkait dengan kegiatan mitigasi AAT. Wilayah pengelolaan AAT pada lahan pasca tambang ditentukan dari batasan catchment area. Sumber air asam tambang dapat dimitigasi menggunakan foto udara dan data penginderaan jauh lainnya. Dalam perencanaan pengelolaan AAT dengan hutan rawa buatan di lahan pasca tambang di wilayah penelitian direkomendasikan menanam jenis tanaman yang tahan di air asam dan hyperaccumulator seperti Typha latifolia, Salvinia sp., Fimbristylis globulosa, Chrysopogon zizanioides, Melaleuca leucadendra, Melaleuca cajuputi, Nauclea subdita dan Nauclea orientalis L. Lokasi yang sesuai untuk hutan rawa harus memperhatikan elevasi (T), kemiringan lahan (S), penutupan lahan (L), cathment area (C), jarak dari saluran/kanal $(\mathrm{K})$ dan jarak dari kolam monitoring $(\mathrm{P})$ yang dapat ditentukan dengan persamaan model $\mathrm{X}=0.2 \mathrm{~T}+0.2 \mathrm{~S}+0.1 \mathrm{~L}+0.15 \mathrm{C}+0.3 \mathrm{~K}+0.05 \mathrm{P}$. Desain hutan rawa disusun parallel yang terdiri dari kolam sedimen, dan kolam lainnya dengan substrat dasar dari tandan kosong dan kompos dan dialiri air sedalam 30 $\mathrm{cm}$. Kolam sedimen berfungsi agar dapat mengurangi pendangkalan di hutan rawa dan memudahkan perawatan. 


\section{UCAPAN TERIMA KASIH}

Penulis mengucapkan terima kasih kepada SEAMEO BIOTROP dan Global Innovation Initiative (GII) Project untuk dukungan pendanaan dalam kegiatan penelitian, kepada Prof. Jerry R. Miller dari Western Carolina University, North Carolina Amerika Serikat, atas segala bimbingan dan bantuannya selama 3 bulan penulis mengikuti kegiatan Student Exchange demi menambah ilmu untuk mendukung kegiatan penelitian ini.

\section{DAFTAR PUSTAKA}

Alibasyah R. 2016. Perubahan beberapa sifat fisika dan kimia ultisol akibat pemberian pupuk kompos dan kapur dolomit pada lahan berteras. Jurnal Floratek. 11(1): 75-87.

Bonanno G, Cirelli GL. 2017. Comparative analysis of element concentrations and translocation in three wetland congener plants: Typha domingensis, Typha latifolia and Typha angustifolia. Ecotoxicology and Environmental Safety. 143(1): 92 - 101. doi:10.1016/j.ecoenv.2017.05.021.

Chunkao K, Nimpee C, Duangmal K. 2012. The King's initiatives using water hyacinth to remove heavy metals and plant nutrients from wastewater through Bueng Makkasan in Bangkok Thailand. Ecological Engineering. 39 (1): 40 - 52. doi:10.1016/j.ecoleng.2011.09.006.

Denholm CP, T P Danehy, M H. Dunn, S L Busler, C A. Neely, R M. Mahony, D A. Guy. 2016. Long-Term Effectiveness Of Three Passive Systems Treating Acidic, High-Metal, Abandoned Coal Mine Discharges Near De Sale, Pennsylvania [Internet]. [33rd Annual Meeting of the ASMR, June 4-9, 2016, Spokane, Washington]. Washington: ASMR.; [diunduh 2017 Okt 7]. Tersedia pada: https://www.asmr.us/Portals/0/Documents/Meetings/2016/16-01-Denholm.pdf.

Dhir B. 2013. Phytoremediation: Role of Aquatic Plants in Environmental CleanUp. New Delhi: Springer.

Direktorat Jenderal Mineral dan Batubara. 2013. Kumpulan Pedoman Teknis Lingkungan Pertambangan. Kementerian Energi dan Sumber Daya Mineral. Jakarta (31): Direktorat Jenderal Mineral dan Batubara.

Gautam M, Agrawal M. 2017. Phytoremediation of metals using vetiver (Chrysopogon zizanioides (L.) Roberty) grown under different levels of red mud in sludge amended soil. Geochemical Exploration. doi:10.1016/j.gexplo.2017.03.003.

Hairiah K, Sardjono MA, Sabarnurdin S. 2003. 4 Pemecahan Masalah: Upaya Menuju Pertanian Berkelanjutan. [Internet]. [Waktu dan tempat pertemuan tidak diketahui]. Bogor: [diunduh 2017 Okt 5]. Tersedia pada: http://www.worldagroforestry.org/SEA/Publications/Files/ book/BK0028-04/BK002804-3.pdf.

Iskandar, Sujatmiko, and Gautama RS. 2011. Acid Mine Drainage Management in Indonesian Mines [Internet]. [7th Australian Workshop on AMD held in Darwin on June 21-24, 2011]. Darwin (AU): [diunduh 2017 Okt 5]. Tersedia pada: https://amdworkshop.com.au/files/1168/7th\%20AMD $\% 20$ Front $\% 20$ Pages\%20of\%20Proceedings.pdf

Juniarto A. 2017. Kompos Tandan Kosong Sawit untuk Meningkatkan Pertumbuhan Samama (Neolamarckia macrophylla Roxb.) di Lahan Pasca Tambang Batubara [tesis]. Bogor: Institut Pertanian Bogor.

Mays PA, Edwards GS. 2001. Comparisaon of Heavy metal accumulation in natural wetland and constructed wetlands receiving acid mine drainage. Ecol Eng. 16(4):487-500. doi:10.1016/S0925-8574(00)001129.

Muzaiyanah S dan Subandi. 2016. Peranan bahan organik dalam peningkatan produksi kedelai dan ubi kayu pada lahan kering masam. Jurnal Iptek Tanaman Pangan. 11(2): 149 -158.

Nairm 2016. Comprehensive Watershed Restoration via Ecological Engineering: The Role of Passive Treatment. [Internet]. [33rd Annual Meeting of the ASMR, June 4-9, 2016, Spokane, Washington]. Washington: ASMR.; [diunduh 2017 Okt 7]. Tersedia pada: https://www.asmr.us/Portals/0/ Documents/Meetings/2016/13-02-Nairn.pdf 
Norton PJ. 1992. The control of acid mine drainage with wetlands. Mine Water Environ. 11(3):27-34. doi:10.1007/BF02914814.

Nurjanah AS. 2014. Potensi Simpanan Karbon Pada Tegakan Revegetasi Lahan Pasca Tambang PT Jorong Barutama Greston, Kalimantan Selatan [skripsi]. Bogor: Institut Pertanian Bogor.

Rafsanjani A. 2015. Pengaruh Bahan Organik Terhadap Eh dan pH, serta Korelasinya terhadap P Tersedia pada Tanah yang Digenangi [skripsi]. Bogor: Institut Pertanian Bogor.

Sasaki K, Ogino T, Endo Y, Kurosawa K. 2003. Field study on heavy metal acumulation in natural wetland receiving acid mine drainage. Mater Trans. 44(9):1877-1884.

Scheneider IAH, Rubio J, Misra M, Smith RW. 1995. Eichhornia Crassipes as biosorbent for heavy metal ions. Miner Eng. 8(9): 979 - 988. doi: 10.1016/0892-6875(95)00061-T.

Sengupta M. 1993. Environmental Impacts Of Mining, Monitoring, Restoration, And Control. New York: Lewis Publishers.

Sheoran AS, Sheoran V. 2006. Heavy metal removal mechanism of acid mine drainage in wetlands: A critical review. Miner Eng. 19(2):105-116. doi: 10.1016/j.mineng.2005.08.006.

Tuheteru FD. 2015. Potensi Lonkida (Nauclea Orientalis L.) Untuk Fitoremediasi Lahan Basah Air Asam Tambang [disertasi]. Bogor: Institut Pertanian Bogor.

Wetland Stewarship Partnership. 2009. Wetland Ways; Interim Guidelines for Wetland Protection and Conservation in British Colombia. Chapter 11: Wetland Enhancement and Restoration. British Colombia: Environmental Stewardship Division.

Widiyatmoko R, Wasis B, Prasetyo LB. 2017. Analisis pertumbuhan tanaman revegetasi di lahan bekas tambang silika holcim educational forest Cibadak, Sukabumi, Jawa Barat. Jurnal Pengelolaan Sumberdaya Alam dan Lingkungan. 7(1): 79-88. doi : 10.19081/jps1.2017.7.1.79. 